\title{
RADIOCARBON INVESTIGATION OF THE PEDUNCULATE OAK OF BOTOSANA, ROMANIA
}

\author{
ADRIAN PATRUT'a, ${ }^{*}$, NICOLAE ROBU ${ }^{b}$, VASILE SAVU, \\ ROXANA T. PATRUT ${ }^{\mathrm{a}, \mathrm{c}}$, LASZLO RAKOSYc, ILEANA-ANDREEA RATIU ${ }^{\mathrm{a}}$, \\ DANIEL A. LOWY ${ }^{d}$, DRAGOS MARGINEANUa, KARL F. VON REDEN ${ }^{\mathrm{e}}$
}

\begin{abstract}
The article discloses the AMS (accelerator mass spectrometry) radiocarbon dating results of the pedunculate oak of Botoşana. Four wood samples were extracted from its trunk. Five segments extracted from these samples were analyzed by AMS radiocarbon. Their radiocarbon dates were found to be between $161 \pm 21 \mathrm{BP}$ and $260 \pm 20 \mathrm{BP}$. These values correspond to calibrated ages of 235 - 365 years. The dating results extrapolated to the geometric center of the trunk indicate an age of $645 \pm 50$ years for the oak of Botoşana.
\end{abstract}

Keywords: AMS radiocarbon dating, Quercus robur, dendrochronology, age determination.

\section{INTRODUCTION}

The pedunculate oak (Quercus robur L.), also called European oak or English oak, belongs to the family Fagaceae and is native to Europe, western Asia and northern Africa. This upright, columnar tree is typically $20-30 \mathrm{~m}$ tall, in

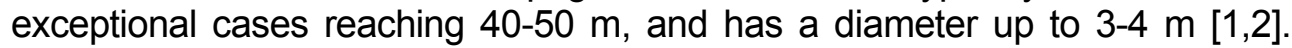
The pedunculate oak is considered one of the most long-lived European trees.

a Babeş-Bolyai University, Faculty of Chemistry and Chemical Engineering, 11 Arany Janos, RO-400028, Cluj-Napoca, Romania.

*Corresponding author: apatrut@gmail.com

b Technological High School "Ştefan cel Mare", 526 Principală, RO-727100, Cajvana, Romania.

c Babeş-Bolyai University, Faculty of Biology and Geology, 44 Republicii, RO-400015, Cluj-Napoca, Romania.

d Valor Hungariae, Dept. of Science and Innovation, 4 Nagysándor József, 1054 Budapest, Hungary.

e NOSAMS Facility, Dept. of Geology \& Geophysics, Woods Hole Oceanographic Institution, Woods Hole, MA 02543, U.S.A. 
In 2005, we started a long term research for elucidating several controversial aspects concerning the African baobab. The research is based on our new approach which enables to investigate and date standing live specimens. This approach consists of AMS radiocarbon dating of tiny wood samples collected from different areas of such trees [3-8]. We extended our research by also investigating individuals which belong to other angiosperm species, including trees from Romania.

Romania hosts several trees which have reached large dimensions and old ages. We investigated and dated by radiocarbon some remains of the historic oak of Tebea [9], the large pedunculate oak of Cajvana [10], the old black poplar of Mocod and the big grey poplar of Rafaila [11], and the old ash of Aiton [12].

Here we present the AMS radiocarbon dating results of another old Romanian tree, namely the pedunculate oak of Botoşana.

\section{RESULTS AND DISCUSSION}

The pedunculate oak of Botoşana and its area. The large oak is located in the garden of a privately-owned house in the commune Botoşana, Suceava county, at $37 \mathrm{~km} \mathrm{~W}$ of Suceava, in the north-eastern part of Romania. Its GPS coordinates are 47040.690' N, 02556.52' E and the altitude is $488 \mathrm{~m}$. The mean annual rainfall in the area is around $579 \mathrm{~mm}$ (Suceava station). The oak of Botoşana is located at only $4 \mathrm{~km} \mathrm{SW}$ from the pedunculate oak of Cajvana which is the largest and oldest oak in Romania.

The oak of Botoşana has today a maximum height of $22.5 \mathrm{~m}$ with a broken top and the circumference at breast height (cbh; at $1.30 \mathrm{~m}$ above mean ground level) is $9.14 \mathrm{~m}$. Its circumference at ground level is $9.38 \mathrm{~m}$, reaching a maximum value of $10.45 \mathrm{~m}$ at the height of $2.80 \mathrm{~m}$. The calculated overall wood volume is $55 \mathrm{~m}^{3}$, out of which the trunk has $40 \mathrm{~m}^{3}$.

The very irregular trunk has many sinuosities. Seven primary branches emerge from the trunk at different heights, some of them having diameters up to $1 \mathrm{~m}$. The horizontal dimensions of the remaining canopy are $18.3(\mathrm{NS}) \times 21.2(\mathrm{WE}) \mathrm{m}$. A photograph taken around 1900 shows that the height of the oak exceeded $30 \mathrm{~m}$ and it had a much larger canopy. The tree was struck by lightning in the first half of the $20^{\text {th }}$ century. The oak is in a state of decline which started more than a century ago. It has many dry branches and it is suffering from a complex disease called "chronic oak dieback or decline". In this disease, several biotic and abiotic agents interact and bring about a severe deterioration of the tree condition [13]. The percentage of dry branches in the canopy has increased continuously from $5 \%$ in 1900 (Figure 1a) to almost $40 \%$ today (Figure 1b). The Romanian Academy nominated the Botoşana oak as a Monument of Nature. 
Wood samples. A number of four wood samples were extracted from the outer part of the tree around the circumference. The four samples (labelled 1 to 4 ) have lengths between 0.51 and $0.77 \mathrm{~m}$. The heights of the sampling points were between 1.70 and $2.10 \mathrm{~m}$. The deepest end of each sample (marked as 1a, 2a, 3a and 4b), as well as an intermediate segment (marked $4 a$ ) were extracted for radiocarbon dating.

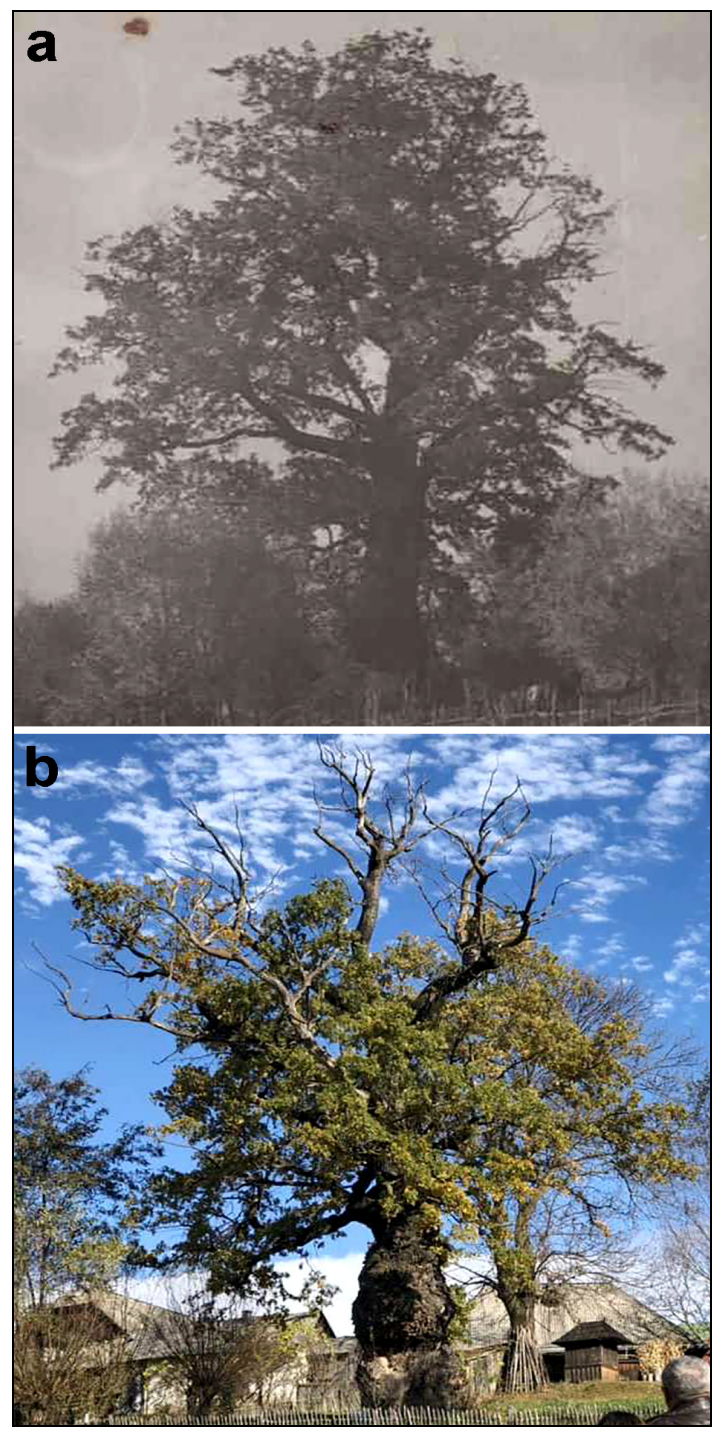

Figure 1. a. General view of the oak of Botoşana on a photograph taken around 1900; b. The oak of Botoşana in 2018. 
AMS results and calibrated ages. Radiocarbon dates of the deepest segments extracted from the four samples and also of another segment of sample 4, are listed in Table 1. Radiocarbon dates and errors were rounded to the nearest year. Radiocarbon dates are expressed in ${ }^{14} \mathrm{C}$ yr BP (radiocarbon years before present, i.e., before the reference year AD 1950).

Calibrated (cal) ages, expressed in calendar years, are also shown in Table 1. The 1- $\sigma$ probability distribution was selected to derive calibrated age ranges. For the oldest sample segment $4 \mathrm{~b}$, the 1- $\sigma$ distribution corresponds to one range of calendar years. For the other four segments, the $1-\sigma$ distribution corresponds to three or four ranges of calendar years. For these segments, the confidence interval of one range is considerably greater than that of the others; therefore, it was selected as the cal AD range of the segment for the purpose of this discussion. For obtaining single calendar age values of sample segments, we derived a mean calendar age of each segment from the selected range (marked in bold). Calendar ages of segments represent the difference between AD 2018 and the mean value of the selected range, with the corresponding error. Calendar ages and errors were rounded to the nearest $5 \mathrm{yr}$.

Table 1. AMS radiocarbon dating results and calibrated calendar ages of samples/segments collected from the oak of Botoşana.

\begin{tabular}{|c|c|c|c|c|}
\hline $\begin{array}{c}\text { Sample } \\
\text { (Segment) } \\
\text { code }\end{array}$ & $\begin{array}{c}\text { Depth }^{1} \\
\left.\text { [height }^{2}\right] \\
\left(10^{-2} \mathrm{~m}\right)\end{array}$ & $\begin{array}{c}\text { Radiocarbon date } \\
\text { [error] } \\
\left({ }^{14} \mathrm{C} \text { yr BP }\right)\end{array}$ & $\begin{array}{c}\text { Cal AD ranges } \\
1-\sigma \\
\text { [confidence interval] }\end{array}$ & $\begin{array}{c}\text { Sample age } \\
\text { [error] } \\
\text { (cal yr) }\end{array}$ \\
\hline $1 \mathrm{a}$ & $\begin{array}{c}51 \\
{[195]}\end{array}$ & $161[ \pm 21]$ & $\begin{array}{c}1670-1685[10.5 \%] \\
1732-1778[38.8 \%] \\
1798-1808[7.1 \%] \\
1928-1942[11.8 \%]\end{array}$ & $265[ \pm 25]$ \\
\hline $2 a$ & $\begin{array}{c}53 \\
{[185]}\end{array}$ & $172[ \pm 23]$ & $\begin{array}{c}1669-1682[12.1 \%] \\
\mathbf{1 7 3 6 - 1 7 8 1}[\mathbf{4 1 . 0 \%}] \\
1798-1805[5.6 \%] \\
1935-1946[9.5 \%]\end{array}$ & $260[ \pm 20]$ \\
\hline $3 a$ & $\begin{array}{c}56 \\
{[170]}\end{array}$ & $203[ \pm 26]$ & $\begin{array}{c}1658-1678[19.2 \%] \\
1764-1800[33.4 \%] \\
1940-\ldots[15.6 \%]\end{array}$ & $235[ \pm 20]$ \\
\hline $4 a$ & $\begin{array}{c}55 \\
{[210]}\end{array}$ & $175[ \pm 22]$ & $\begin{array}{c}1668-1682[12.7 \%] \\
1736-1782[39.5 \%] \\
1798-1804[5.4 \%] \\
1936-1948[10.5 \%]\end{array}$ & $260[ \pm 15]$ \\
\hline $4 \mathrm{~b}$ & $\begin{array}{c}77 \\
{[210]}\end{array}$ & $260[ \pm 20]$ & $1640-1664[68.2 \%]$ & $365[ \pm 10]$ \\
\hline
\end{tabular}

1 Depth in the wood from the sampling point.

2 Height above ground level. 
Dating results of samples (segments). The deepest part/end of the collected samples, i.e, $1 \mathrm{a}, 2 \mathrm{a}, 3 \mathrm{a}$ and $4 \mathrm{~b}$, have radiocarbon dates between $161 \pm 21 \mathrm{BP}$ and $260 \pm 20 \mathrm{BP}$. These values correspond to calibrated ages between $235 \pm 20$ and $365 \pm 10 \mathrm{yr}$.

The calibration, namely the conversion of radiocarbon dates into calendar ages, can be discussed in particular cases. Thus, the calibration of wood samples with calendar/dendro ages in the time frame AD 1640 1950 shows some uncertainties. In such cases, the calibration of one radiocarbon date may result in up to four, five or six calendar age ranges. This is due to the so-called "Suess effect", which expresses the significant variation of the atmospheric radiocarbon concentration due to the combustion of fossil fuels $[14,15]$.

Age of the oak of Botoşana. The radial increment of trees, measured by the radial growth rate, is typically influenced by the tree species, tree age, biological and genetic properties, environmental conditions, climatic factors, water table, etc. [16]. The pedunculate oak is one of the species for which the mean annual growth rate of an individual over several decades shows relatively constant values. Therefore, the radial increment is a parameter which can be used for the age determination of oaks.

For establishing the age of the investigated oak, we calculated the distances of the oldest dated segment, i.e., $4 \mathrm{~b}$, to the bark and to the geometric center of the trunk, respectively. Next, we extrapolated the age of this segment to the geometric center, by considering that the mean growth rate was almost constant. Sample 4 was collected at a height of $2.10 \mathrm{~m}$, where the circumference of the trunk is $8.64 \mathrm{~m}$ and the bark thickness $0.05 \mathrm{~m}$. These values correspond to a diameter inside bark of $2.72 \mathrm{~m}$ and a related radius of $1.36 \mathrm{~m}$. The sample segment $4 \mathrm{~b}$ originates from a distance of $0.77 \mathrm{~m}$ from the bark and $0.59 \mathrm{~m}$ from the geometric center. By extrapolating its age of $365 \mathrm{yr}$ to the geometric center, we obtain an age of $645 \mathrm{yr}$. Calculations for the other deep segments $1 \mathrm{a}, 2 \mathrm{a}$ and $3 \mathrm{a}$ yielded similar values, hence showing that the geometric center and the true pith of the trunk, at this height, are very close to one another.

The radiocarbon dating results and their extrapolation to the pith indicate and age of $645 \pm 50 \mathrm{yr}$ for the investigated oak. One can state that the oak of Botoşana started growing around the year $A D$ 1375, more precisely in the time frame $1325-1425$.

\section{CONCLUSIONS}

Our research presents the AMS radiocarbon dating results of the pedunculate oak of Botoşana. The main aim of our investigation was to determine the age of tree. Four wood samples were collected from its trunk. 
Five segments were extracted from the samples, including their deepest ends, processed and then dated by AMS radiocarbon. The five segments have radiocarbon dates between $161 \pm 21 \mathrm{BP}$ and $260 \pm 20 \mathrm{BP}$, which correspond to calibrated ages between $235 \pm 20$ and $365 \pm 10 \mathrm{yr}$. These results, extrapolated to the geometric center of the trunk, indicate an age of $645 \pm 50 \mathrm{yr}$ for the investigated oak of Botoşana.

\section{EXPERIMENTAL SECTION}

Size measurements. The height of the oak was measured using a Bosch DLE 70 Professional laser rangefinder. The circumference at different heights was measured with graduated tapes. The volume was calculated from laser measurements of the trunk and of large branches at different heights.

Sample collection. The four wood samples were collected with a Haglöf $\mathrm{CH} 800$ increment borer ( $80 \mathrm{~cm}$ length, $0.54 \mathrm{~cm}$ inner diameter). A number of four tiny pieces/segments of the length of $0.1 \mathrm{~cm}$ were extracted from the deepest end of each sample. One additional segment was extracted from sample 4. The segments were processed and investigated by AMS radiocarbon dating.

Sample preparation. The standard acid-base-acid pretreatment method was used for removing soluble and mobile organic components. The pretreated samples were combusted to $\mathrm{CO}_{2}$ by using the closed tube combustion method. Next, $\mathrm{CO}_{2}$ was reduced to graphite on iron catalyst, under hydrogen atmosphere [17]. Finally, the resulting graphite samples were analyzed by AMS.

AMS measurements. AMS radiocarbon measurements were performed at the NOSAMS Facility of the Woods Hole Oceanographic Institution (Woods Hole, MA, U.S.A.) by using the Pelletron ${ }^{\circledR}$ Tandem 500 kV AMS system. The obtained fraction modern values, corrected for isotope fractionation with the normalized $\delta^{13} \mathrm{C}$ value of $-25 \%$, were ultimately converted to a radiocarbon date.

Calibration. Radiocarbon dates were calibrated and converted into calendar ages with the OxCal v4.3 for Windows [18], by using the IntCal13 atmospheric data set [19].

\section{ACKNOWLEDGMENTS}

The research was funded by the Romanian Ministry of Research and Innovation CNCS-UEFISCDI under grant PN-III-P4-ID-PCE-2016-0776, Nr. 90/2017. 


\section{REFERENCES}

1. P.H. Raven, G.B. Johnson, J.B. Losos, S.R. Singer, "Biology: Seventh Edition", McGraw Hill, New York, 2005.

2. A. le Hardÿ de Beaulieu, T. Lamant, "Le guide illustré des chênes", Vol. 1-2, Huitième, Paris, 2007.

3. A. Patrut, K.F. von Reden, D.A. Lowy, A.H. Alberts, J.W. Pohlman, R. Wittmann, D. Gerlach, L. Xu, C. Mitchell, Tree Physiology, 2007, 27, 1569.

4. A. Patrut, K.F. von Reden, R. Van Pelt, D.H. Mayne, D.A. Lowy, D. Margineanu, Annals of Forest Science, 2011, 68, 993.

5. A. Patrut, S. Woodborne, K.F. von Reden, G. Hall, M. Hofmeyr, D. Lowy, R.T. Patrut, PLOS ONE, 2015, 10(1), e0117193, doi: 10.1371/journal.pone.0117193.

6. A. Patrut, L. Rakosy, R.T. Patrut, I.A. Ratiu, E. Forizs, D.A. Lowy, D. Margineanu, K.F. von Reden, Studia UBB Chemia, 2016, LXI, 4, 7.

7. A. Patrut, S. Woodborne, K.F. von Reden, G. Hall, R.T. Patrut, L. Rakosy, P. Danthu, J-M. Leong Pock-Tsy, D.A. Lowy, D. Margineanu, Radiocarbon, 2017, 59(2), 435.

8. A. Patrut, S. Woodborne, R.T. Patrut, L. Rakosy, D.A. Lowy, G. Hall, K.F. von Reden, Nature Plants, 2018, 4, 423.

9. A. Patrut, K.F. von Reden, D.A. Lowy, S. Pasca, L. Kekedy-Nagy, I. Sovago, Studia UBB Chemia, 2010, LV, 1, 113.

10 A. Patrut, K.F. von Reden, V. Savu, D.A. Lowy, R. Mitea, I. Barbul, Studia UBB Chemia, 2011, LVI, 1, 145.

11. A. Patrut, K.F. von Reden, D.A. Lowy, R.T. Patrut, D.L. Vaida, D. Margineanu, Nuclear Instruments and Methods in Physics Research Section B, 2013, 294, 616.

12. A. Patrut, R.T. Patrut, L. Rakosy, I.A. Ratiu, D.A. Lowy, J. Bodis, K.F. von Reden, Studia UBB Chemia, 2018, LXIII, 3, 41.

13. J.N. Gibbs, B.J.W. Greig, Forestry, 1997, 70, 399.

14. P.P. Tans, A.F.M. de Jong, W.G. Mook, Nature, 1979, $280,826$.

15. M. Worbes, Dendrochronologia, 2002, 20 (1-2), 217.

16. J. Ruseckas, Ekologija, 2006, 1, 16.

17. A. Patrut, S. Woodborne, R.T. Patrut, L. Rakosy, G. Hall, I.A. Ratiu, K.F. von Reden, Studia UBB Chemia, 2017, LXII, 2, 347.

18. C. Bronk Ramsey, Radiocarbon, 2009, 51, 337.

19. P.J. Reimer, E. Bard, A. Bayliss, J.W. Beck, P.G. Blackwell, C. Bronk Ramsey, C.E. Buck, H. Cheng, R. Lawrence Edwards, M. Friedrich, P.M. Grootes, T.P. Guilderson, H. Haflidason, I. Hajdas, C. Hatte, T.J. Heaton, D.L. Hoffman, A.G. Hogg, K.A. Hughen, K.F. Kaiser, B. Kromer, S.W. Manning, M. Niu, R.W. Reimer, D.A. Richards, E.M. Scott, J.R. Southon, R.A. Staff, C.S.M. Turney, J. van der Plicht, Radiocarbon, 2013, 55(4), 1869. 
